\title{
Life History and Habitat Associations of the Broad Wood Cockroach, Parcoblatta lata (Blattaria: Blattellidae) and Other Native Cockroaches in the Coastal Plain of South Carolina
}

\author{
SCOTT HORN ${ }^{1}$ AND JAMES L. HANULA \\ USDA Forest Service, Southern Research Station, 320 Green Street, Athens, GA, 30602-2044
}

Ann. Entomol. Soc. Am. 95(6): 665-671 (2002)

\begin{abstract}
Wood cockroaches (Blattaria: Blattellidae) are important prey of the red-cockaded woodpecker, Picoides borealis Wilson (Piciformes: Picidae), an endangered species inhabiting pine (Pinus spp.) forests in the southern United States. These woodpeckers forage on the boles of live pine trees, but their prey consists of a high proportion of wood cockroaches, Parcoblatta spp., that are more commonly associated with dead plant material. Consequently, we sampled large woody debris, logs and standing dead trees (snags), in a South Carolina pine forest to determine densities of wood cockroaches in these habitats. Nearly $80 \%$ of the 662 wood cockroaches we collected from woody debris were found in snags. However, when we estimated the number of wood cockroaches per hectare, we found that the two habitats contained approximately equal numbers because logs are more abundant than snags. The broad wood cockroach, Parcoblatta lata Brunner, was the most common cockroach on live pine boles constituting $46 \%$ of the wood cockroaches. Males were present from late April to late July in field studies suggesting that $P$. lata has only one generation per year, which is consistent with laboratory studies in which males lived an average of $91.3 \mathrm{~d}$. Female $P$. lata lived almost twice as long $(158.2 \mathrm{~d})$ and produced an average of 12.6 oothecae/female $(\mathrm{SE}=3.4)$ or $\approx 517$ offspring/ female. Although P. lata were common on boles of live trees, our results show that snags and logs also are important habitats of these wood cockroaches in pine forests.
\end{abstract}

KEY WORDS coarse woody debris, wood cockroaches, Parcoblatta lata, red-cockaded woodpecker, Picoides borealis, snags

Approximately 69 COCKROACH species occur in the United States and Canada, of which 24 are considered exotics (Atkinson et al. 1991). Many have been studied extensively because they directly affect humans, but little is known about the life histories of common woodland species. Blatchley (1920) and Lawson (1967) provided general habitat descriptions for Parcoblatta spp., and Brimley (1908) and Hebard (1917) provided anecdotal accounts of Parcoblatta lata Brunner occurring under pine logs and in stumps. Rau (1940) noted longevity, molting, and natural enemies for Parcoblatta pennsylvanica DeGeer in Missouri; and Gorton (1980a, 1980b) conducted laboratory and field studies on intraspecific and interspecific interactions of wood cockroaches in Kansas. Dakin and Hays (1970) and Helfer (1987) published taxonomic keys to distinguish wood cockroaches, but provided little information on natural history.

Wood cockroaches in the genus Parcoblatta are important prey of the red-cockaded woodpecker, $P i$ coides borealis Wilson (Hanula and Franzreb 1995, Hanula and Engstrom 2000, Hanula et al. 2000), and, therefore, must be considered when managing south-

\footnotetext{
${ }^{1}$ E-mail: shorn01@fs.fed.us.
}

ern pine forests for recovery of this endangered species. Red-cockaded woodpeckers are generalist predators that eat arthropods they find on the boles of live pine trees. Although the woodpeckers are the focus of much of the forest management where they occur, wood cockroaches are common bark inhabitants (Hebard 1917; Gorton 1980a, 1980b) that are likely to be important to other bark-foraging birds as well. Even though red-cockaded woodpeckers find wood cockroaches on boles of live trees or in dead branches (Hanula and Franzreb 1998), these cockroaches are not exclusive to this habitat. They are also commonly associated with decomposing logs, leaf litter, and other forest debris (Cantrall 1943; Gorton 1980a, 1980b, Brenner 1988). However, efforts to recover wood cockroaches from leaf litter and stump holes in the foraging habitats of red-cockaded woodpeckers yielded very few individuals compared with dead trees (JLH, unpublished data).

Coarse woody debris (CWD), consisting of standing dead trees (snags), downed logs, and decomposing root systems, is an important part of productive forest ecosystems (Harmon et al. 1986, McMinn and Crossley 1996). In upland forests, CWD can provide a base for new tree growth, harbor fungi, and support a di- 
verse insect and wildlife fauna (Elton 1966, Harmon et al. 1986, Bolen and Robinson 1995, McMinn and Crossley 1996). CWD may be an important habitat component of southern pine forests where wood cockroaches seek refuge during daylight hours, shelter from severe weather or predation, seek food, or mate and oviposit. Forests managed with short rotations, commercial thinning, or timber harvesting practices that leave few snags may result in less CWD (Carmichael and Guynn 1983; McCarthy and Bailey 1994) and, therefore, fewer wood cockroaches, if large woody debris is an important habitat for them.

Our objectives were to determine the relative importance of snags and logs as habitats for cockroaches and determine which cockroach species were present in them. In addition, we wanted to know which species were active on live tree boles at night and which were likely to remain there during the day. The broad wood cockroach, $P$. lata, was the most common species in the study area, so we determined when $P$. lata males were present in the field, and we reared $P$. lata in the laboratory to determine adult longevity and fecundity. We also recorded observations of predation on wood cockroaches and provide a list of other associates found in CWD and beneath burlap bands on live trees.

\section{Materials and Methods}

Site. The study was conducted at the Savannah River Site $\left(32.2^{\circ} \mathrm{N}, 81.4^{\circ} \mathrm{W}\right)$, a National Environmental Research Park located near Aiken, SC. Longleaf, Pinus palustris (Miller), and loblolly pine, Pinus taeda L., are the dominant overstory trees on the site, which is located in the upper Atlantic Coastal Plain. All stands used in this study were $40-45$ yr old even-aged loblolly pine. Common understory plants included wax myrtle (Myrica cerifera L.), yellow jessamine [Gelsemium sempervirens (L.) Aiton f.], summer grape (Vitis aestivalis Michaux), and poison oak (Toxicodendron pubescens $\mathrm{P}$. Mill).

Woody Debris Sampling. We sampled a total of 25 pine snags and 27 pine logs for wood cockroaches between May and September 1999. Each piece was carefully torn apart, and wood cockroaches were removed so they were only counted once. Wood cockroaches in logs were collected from the entire tree bole below the crown. Snags were less common and most resulted from wind breakage, although some were whole trees. We sampled the lower part of snags that could be reached from the ground (2-3 m height). For logs and snags, we recorded the length or height of the area sampled and the diameter at the midpoint of the sampled area and used Hüber's equation (Avery $1975)$ to estimate cubic volume $\left(\mathrm{m}^{3}\right)$ of wood sampled. Burned trees or those with tight bark were not sampled because they rarely contained wood cockroaches.

The numbers of wood cockroaches per cubic meter of snags and downed logs were multiplied by the cubic volume of CWD in 40-45 yr old loblolly pine stands (B. Edwards, personal communication) to estimate the number of wood cockroaches that might be found per hectare in those habitats in a typical pine stand in our study area.

Cockroaches were identified to species using taxonomic keys (Dakin and Hays 1970, Helfer 1987), and identifications were confirmed by C. Gemeno (NC State University). Voucher specimens are in the USDA Forest Service reference collection in Athens, GA.

Nocturnal Observation. Wood cockroach species commonly found on the bark of live pines at night were determined along 12 150-m long transects through four 40-45 yr old loblolly pine stands. Each stand had three transects. We walked six transects the first night of sampling and the other six transects the following night. Using a white-light flashlight, we examined each tree intersected by a transect up to a height of $3 \mathrm{~m}$ and recorded the number and species of wood cockroaches observed. Only adults were recorded because nymphs could not be identified to species. Species were identified in the field on the basis of coloration and size. Specimens were collected periodically to confirm field identifications. We examined a total of 900 trees in this way from May to August 1999.

Nondestructive Sampling. We used burlap bands wrapped around trees and cardboard panels placed on the ground throughout eight 6-ha plots in mature loblolly pine stands (one plot/stand). Burlap bands were $1 \times 1-\mathrm{m}$ pieces of burlap folded in half and sewn at the top along the fold $\approx 4 \mathrm{~cm}$ from it. A cotton rope was threaded through the space between the fold and sewn seam. The burlap was wrapped around the tree at a height of 1-1.5 m, where it was tied in place with the cotton rope. Burlaps were placed around 30 trees / plot distributed in three rows of 10 burlap bands, so they were equally distributed throughout the plot. Cardboard panels consisted of four layers of $0.5 \times$ $0.75 \mathrm{~m}$ corrugated cardboard held together with gray duct tape. The panels were placed in contact with mineral soil 1-3 $\mathrm{m}$ away from each tree that had a burlap band. Burlap bands and cardboard panels were monitored monthly from July 1998 to September 1999. Wood cockroaches and other arthropods hiding beneath them were identified and counted at each check, and acts of predation on roaches were noted. We created a reference collection by collecting one or two individuals of each arthropod found beneath the burlap or cardboard to aid in identification.

Biological Parameters. Longevity and reproductive capacity of $P$. lata were measured on cockroaches captured as nymphs in October 1998. The nymphs were held in 20-liter plastic buckets and supplied with commercial dog food (American Fare, Troy, MI) and water until the beginning of our study on 8 February 1999. Immature $P$. lata were placed in cylindrical 4 -liter glass containers and held at $25-30^{\circ} \mathrm{C}$ on a $12: 12$ (L:D) photoperiod. Pieces of corrugated cardboard placed in the glass containers gave wood cockroaches a place to hide and a substrate to crawl on. The tops of the containers were covered with wire screen. Wood cockroaches were supplied with $\approx 1 \mathrm{ml}$ of water each day at the time containers were checked for the 
presence of adults. Food was supplied periodically as needed.

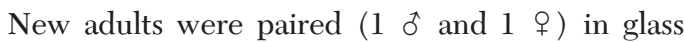
containers (4 liter) and given food and water in the same way. We observed a total of 50 pairs. Pairs were checked daily for: (1) formation of oothecae, (2) deposition of oothecae, and (3) death of either sex. From this information, we calculated the average longevity of each sex, number of oothecae a female produced in her life, how long each oothecae was carried, and the time required to produce an oothecae. We also counted the number of eggs present in 117 oothecae of P. lata. This information was used in combination with the number of oothecae per female to estimate the reproductive potential of wood cockroaches in the wild. Wood cockroaches that escaped or died early were eliminated from analysis. Pairs were checked beginning with the first adult male emergence on 28 March 1999 until the last female died on 13 December 1999.

We measured total body length and pronotal width of field collected adults of all species to aid in future identification. Measurements were made using a digital caliper (Max-Series, Fred V. Fowler Co., Boston) from specimens preserved in $70 \%$ alcohol.

A $t$-test (SAS Institute 1985) was used to test for differences in numbers of wood cockroaches found in snags and logs. Pronotal width and body lengths were analyzed by analysis of variance (ANOVA), and means were separated using the Ryan-Einot-GabrielWelch multiple comparison procedure $(P<0.05$; SAS Institute 1985).

\section{Results}

Woody Debris Sampling. Logs $(n=27)$ averaged $2.81 \mathrm{~m}$ long $( \pm 0.33 \mathrm{SE})$ and $0.20 \mathrm{~m}$ diam $( \pm 0.01)$. The sampled portion of the 25 snags averaged $2.46 \mathrm{~m}$ $( \pm 0.1)$ in length and $0.28 \mathrm{~m}( \pm 0.02)$ in diameter. Although we sampled approximately the same volume of snags and logs, snags contained more than twice as many wood cockroaches (Fig. 1A). Only two species of wood cockroaches were encountered in woody debris. The most common species in both habitats was P. lata, although Parcoblatta fulvescens Saussure \& Zehntner was encountered occasionally. Plots similar to those sampled contained an average volume of $2.14 \mathrm{~m}^{3} / \mathrm{ha}$ of snags and $6.45 \mathrm{~m}^{3} / \mathrm{ha}$ of $\operatorname{logs}$ (B. Edwards, personal communication). The estimated number of wood cockroaches/ ha (Fig. 1B) in large woody debris indicates that snags and logs contained approximately equal numbers.

Nocturnal Observations. Night surveys resulted in 237 observations of adult wood cockroaches on live pine boles. P. lata was the most common species accounting for $46 \%$ of all observations. Aglaopteryx gemma Hebard made up $29 \%$ of our observations, and $P$ arcoblatta divisa Saussure \& Zehntner, P. fulvescens, and Cariblatta lutea lutea Saussure \& Zehntner made up 19,3 , and $3 \%$, respectively.

Nondestructive Sampling. Parcoblatta spp. nymphs were abundant throughout the year under burlap

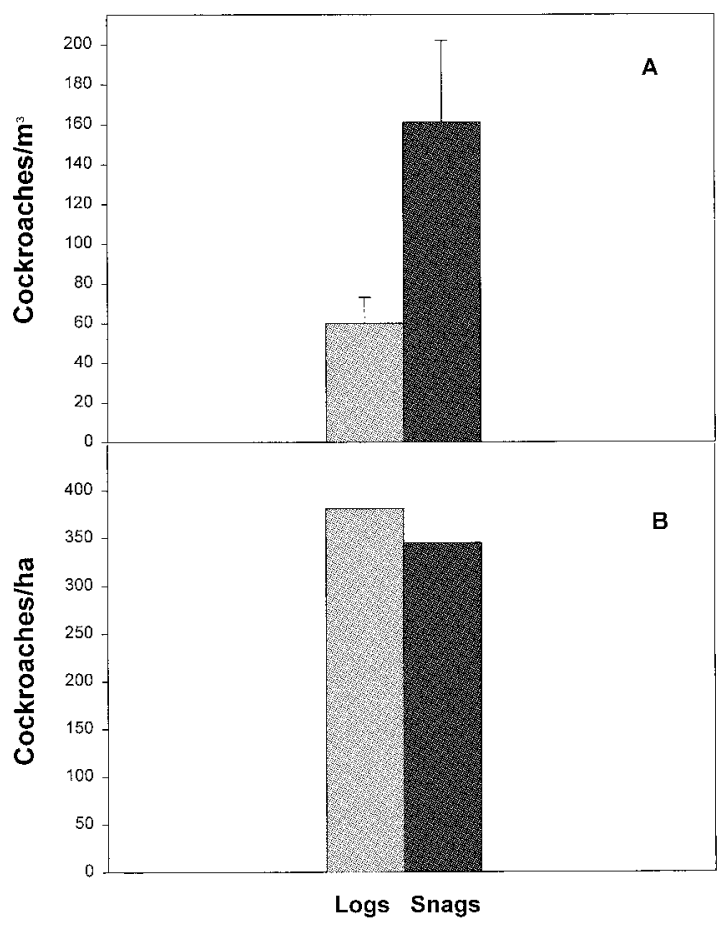

\section{Types of Coarse Woody Debris}

Fig. 1. (A) Comparison of the number of wood cockroaches found per cubic meter of pine logs and snags on the Savannah River Site, SC. Means are significantly different $(P=0.0003, t=-2.36)$. (B) Estimated number of wood cockroaches in coarse woody debris per hectare in pine forests on the Savannah River Site.

bands on tree boles or cardboard panels on the ground (Fig. 2). However, P. lata males were only present from late April through early August. A. gemma, an-

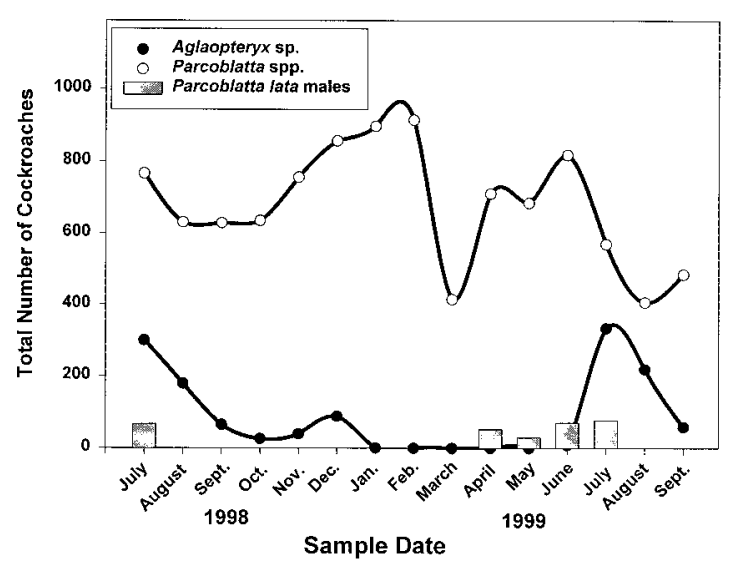

Fig. 2. Seasonal abundance of the two most common wood cockroach genera at the Savannah River Site based on observations made of wood cockroaches beneath burlap bands and cardboard panels from July 1998 to September 1999 . 
Table 1. Common associates of Parcoblatta spp. in an upland pine forest in South Carolina listed by habitat in which they were found

\begin{tabular}{|c|c|c|c|}
\hline \multicolumn{2}{|l|}{ Coarse woody debris } & \multicolumn{2}{|l|}{ Live pine boles } \\
\hline Taxonomic name & Common name & Taxonomic name & Common name \\
\hline Arthropods & & Arthropods & \\
\hline Araneae: Lycosidae: Hogna $a^{a}$ & Wolf spider & Araneae: Salticidae: Phidippus ${ }^{b}$ & Jumping spider \\
\hline Coleoptera: Tenebrionidae: Alobates & Darkling beetle & Araneae: Lycosidae: Hogna ${ }^{b}$ & Wolf spider \\
\hline Coleoptera: Tenebrionidae: Helops & Darkling beetle & Araneae: Agelenidae: Agelenopsis ${ }^{b}$ & Funnel-web spider \\
\hline Coleoptera: Curculionidae: Hylobius & Weevil & Coleoptera: Curculionidae: Hylobius & Weevil \\
\hline Coleoptera: Tenebrionidae: Uloma & Darkling beetle & Coleoptera: Tenebrionidae: Helops & Darkling beetle \\
\hline Hemiptera: Pentatomidae: Brochymena & Stink bug & Hemiptera: Reduviidae: Pselliopus ${ }^{b}$ & Assassin bug \\
\hline Hemiptera: Reduviidae: Microtomus ${ }^{a}$ & Assassin bug & Hemiptera: Pentatomidae: Brochymena & Stink bug \\
\hline Hymenoptera: Formicidae: Camponotus & Carpenter ant & Hemiptera: Pentatomidae: Diolcus & Stink bug \\
\hline Hymenoptera: Formicidae: Crematogaster & Ant & Hymenoptera: Evaniidae: Hyptia ${ }^{b}$ & Ensign wasp \\
\hline Hymenoptera: Formicidae: Pheidole & Ant & Hymenoptera: Formicidae: Camponotus & Carpenter ant \\
\hline Isoptera: Rhinotermitidae: Reticulitermes & Subterranean termite & Hymenoptera: Formicidae: Crematogaster & Ant \\
\hline Scolopendromorpha: Cryptopidae ${ }^{a}$ & Centipede & Hymenoptera: Formicidae: Formica & Ant \\
\hline Scolopendromorpha: Scolopendridae ${ }^{a}$ & Centipede & Hymenoptera: Formicidae: Pheidole & Ant \\
\hline Scorpiones: Buthidae: Centruroides ${ }^{a}$ & Scorpion & Scolopendromorpha: Scolopendridae ${ }^{b}$ & Centipede \\
\hline Vertebrates & & Thysanura: Lepismatidae: Thermobia & Firebrat \\
\hline Squamata: Iguanidae: Sceloporus undulatus ${ }^{a}$ & Fence lizard & Vertebrates & \\
\hline Squamata: Scincidae: Eumeces fasciatus ${ }^{a}$ & Five-lined skink & Piciformes: Picidae: Picoides borealis ${ }^{b}$ & $\begin{array}{r}\text { Red-cockaded } \\
\text { woodpecker }\end{array}$ \\
\hline Squamata: Scincidae: Eumeces laticeps ${ }^{a}$ & Broad headed skink & $\begin{array}{l}\text { Rodentia: Sciuridae: Glaucomys volans }{ }^{b} \\
\text { Squamata: Iguanidae: Anolis carolinensis }{ }^{a} \\
\text { Squamata: Iguanidae: Sceloporus } \text { undulatus }^{a} \\
\text { Squamata: Scincidae: Eumeces fasciatus }{ }^{a} \\
\text { Squamata: Scincidae: Eumeces laticeps }{ }^{b}\end{array}$ & $\begin{array}{l}\text { Flying squirrel } \\
\text { Carolina anole } \\
\text { Fence lizard } \\
\text { Five-lined skink } \\
\text { Broad headed } \\
\quad \text { skink }\end{array}$ \\
\hline
\end{tabular}

Predators were either observed feeding on wood cockroaches, or were considered likely predators based on their general habits and common occurrence in the same habitats as wood cockroaches.

${ }^{a}$ Suspected predators found in a particular habitat.

${ }^{b}$ Act of predation witnessed.

other common species, was abundant during the summer, but it was never observed from January through early June. Parcoblatta spp. varied in their choice of harborages; $55.7 \%$ of the individuals being observed under burlap bands, and the other $44.3 \%$ were found on the ground underneath cardboard panels. In contrast, A. gemma was almost entirely arboreal with 99.5\% of our observations under burlap. Species level observations of Parcoblatta found under the burlap and cardboard were limited by difficulties in identifying immatures.

Table 1 lists common associates (i.e., spiders and ants) of wood cockroaches found in CWD or on live pine boles. We observed three species of spiders, a Reduviidae, and two skink species preying on cockroaches beneath burlap bands or during nocturnal observations. We also noted predators that, based on their general habits, were likely to prey on wood cockroaches but were not observed feeding on them. A number of nonpredatory arthropods also were found associated with wood cockroaches in woody debris. These associates were similar in logs and snags, and similar arthropods were found associated with wood cockroaches throughout the year on live pine boles.

Biological Parameters. We reared and monitored $P$. lata wood cockroaches in the laboratory for $>8 \mathrm{mo}$ (Table 2). Adult males typically appeared before females in the laboratory and in the field (unpublished data). In captivity, females lived an average of $158.2 \mathrm{~d}$, whereas males lived $91.3 \mathrm{~d}$. One female survived $237 \mathrm{~d}$. Females produced oothecae every $7 \mathrm{~d}$ and an average of 12.6 oothecae over a lifetime. Five females produced 20 or more oothecae. The average $P$. lat $a$ oothecae contained 41 eggs, so females produced an average of $\approx 517$ offspring per year.

We also collected and measured adult male and female wood cockroaches to develop size estimates for future field studies (Table 3). Both sexes of P. lata were larger than the other two Parcoblatta spp. we collected.

\section{Discussion}

We found nearly three times as many wood cockroaches in snags compared with logs. Brenner (1988) suggested that peridomestic cockroaches are located in predictable, identifiable habitats. For instance, he and others (Cornwell 1968, Benson 1988) documented the significance of tree holes for cockroaches. In laboratory trials, Appel and Smith (1996) found

Table 2. Mean and range of selected biological parameters of P. lata maintained in the laboratory from March to December 1999

\begin{tabular}{lrcc}
\hline \multicolumn{1}{c}{ Variable } & $\begin{array}{c}\text { Sample } \\
\text { size }\end{array}$ & Mean & Range \\
\hline Male longevity & 34 & $91.3 \mathrm{~d}$ & $20-152 \mathrm{~d}$ \\
Female longevity & 34 & $158.2 \mathrm{~d}$ & $48-237 \mathrm{~d}$ \\
Total oothecae & 34 & 12.6 & $6-21$ \\
Days holding oothecae & 34 & $4.7 \mathrm{~d}$ & $3.38-6.63 \mathrm{~d}$ \\
Days between deposition & 34 & $7.3 \mathrm{~d}$ & $5.13-12.8 \mathrm{~d}$ \\
No. egg chambers & 117 & 41 & $26-46$ \\
Oothecal length/height & 117 & $10 / 3.9 \mathrm{~mm}$ & $6-12 / 3-4 \mathrm{~mm}$ \\
Oothecal biomass & 23 & $0.0556 \mathrm{~g}$ & $0.0411-0.0747 \mathrm{~g}$ \\
\hline
\end{tabular}


Table 3. Mean body length and pronotal width $(\mathrm{mm})( \pm \mathrm{SE})$ of adults of five species of wood cockroaches collected from pine forests on the Savannah River Site, near New Ellenton, SC

\begin{tabular}{|c|c|c|c|c|c|c|}
\hline \multirow{2}{*}{ Species } & \multicolumn{3}{|c|}{ Male } & \multicolumn{3}{|c|}{ Female } \\
\hline & No. & Total length & Pronotal width & No. & Total length & Pronotal width \\
\hline P. lata & 21 & $22.16(0.40) \mathrm{a}$ & $6.31(0.09) \mathrm{a}$ & 16 & $20.86(0.42) \mathrm{a}$ & $7.32(0.13) \mathrm{a}$ \\
\hline P. divisa & 27 & $17.33(0.35) \mathrm{b}$ & $4.89(0.10) b$ & 13 & $14.26(0.40) \mathrm{b}$ & $4.86(0.10) \mathrm{b}$ \\
\hline P. fulvescens & 14 & $15.70(0.28) \mathrm{b}$ & $4.47(0.11) \mathrm{b}$ & 2 & $16.08(0.44) b$ & $5.50(0.11) b$ \\
\hline A. gemma & 13 & $9.55(0.20) \mathrm{c}$ & $2.99(0.05) \mathrm{c}$ & 10 & $9.76(0.27) \mathrm{c}$ & $3.06(0.08) \mathrm{c}$ \\
\hline C. lutea lutea & 2 & $7.86(0.14) \mathrm{d}$ & $2.75(0.05) \mathrm{d}$ & 2 & $7.94(0.12) \mathrm{d}$ & $2.84(0.06) \mathrm{d}$ \\
\hline
\end{tabular}

All measurements were made on individuals preserved in $70 \%$ alcohol. Means within columns followed by same letter are not significantly different $(P=0.05)$ according to the Ryan-Einot-Gabriel-Welsch multiple range test.

pine straw was a preferred harborage for small and medium peridomestic cockroach nymphs. They pointed out that pine straw is favorable to cockroaches because it maintains a constant warm, humid microclimate. Likewise, Brenner (1988) found higher numbers of peridomestic cockroaches in foundation mulches consisting of pine straw compared with other sites without it.

It is unclear why wood cockroaches were more abundant in snags; however, it may be due to the presence of loose bark. Most snags still retained a portion of their bark, often very loosely held in place, that allowed wood cockroaches to hide beneath it. Although wood cockroaches can be found throughout well-rotted portions of logs and snags, they seem to prefer areas where loose bark is present. The preference for snags may be due solely to better hiding places (i.e., from predators) or it could be due to a better microclimate. In previous studies, populations of wood cockroaches held in laboratory conditions of excessively high humidity with little air circulation had high levels of mortality because of Metarhizium sp. fungi (JLH, unpublished data). Several studies indicated that microarthropods survive changes of their localized environment by seeking shelter within crevices or by acclimating physically (Prinzing 2001). Wood cockroaches may prefer snags because they provide a suitable temperature or humidity, or simply because they can change microclimates easily by moving up or down the snag beneath the bark. Therefore, it is possible that stable microhabitats within snags serve as preferred daytime refuges.

Environmental conditions such as relative humidity (Smith et al. 1999), air circulation (Oswalt et al. 1997, Appel and Smith 1999), temperature (Appel et al. 1983, Smith et al. 1999), light levels (Cornwell 1968), and food availability probably influence domestic and wood cockroach habitat selection. Compared with snags, downed logs have a higher moisture content because of greater fungal invasion as a result of more surface contact with the soil (Van Lear 1996). The higher moisture content of logs may be important for oothecal deposition because we observed as many as 20 oothecae in $1 \mathrm{~m}$ of moist log. Similarly, Edmunds (1952) reported finding oothecae deposited in large numbers within logs. Roth $(1966,1968)$ reported that oothecae of Parcoblatta spp. contain insufficient moisture, so it is likely that they depend on favorable environmental conditions to permit egg maturation.
Cochran (1986) suggested that Parcoblatta spp. developed an evolutionary strategy of producing large numbers of eggs to deal with this problem. However, they may also place oothecae in moist habitats such as logs to ensure sufficient moisture for maturation and hatching. We consistently found large numbers of oothecae within moist sections of log, whereas wood cockroach nymphs and adults were usually found in drier sections. Because of their higher moisture content, logs may be particularly important for maintaining populations during drought periods.

Snags harbored greater numbers of cockroaches compared with logs, but logs were more abundant and widely distributed so the two habitats contained equal numbers of wood cockroaches per hectare. We suspect that our estimates of roach use of snags may be conservative because we could only sample snags up to 2-3 $\mathrm{m}$ in height. The high numbers of wood cockroaches occurring in CWD suggests that forestry practices that reduce log and snag abundance would affect wood cockroach abundance. However, that does not appear to be the case based on a short-term study. Annual removal of snags and logs from mature loblolly pine stands did not affect captures of wood cockroaches on live tree boles $2 \mathrm{yr}$ after removal began (Horn 2000). These studies are continuing to determine if cockroaches can maintain their populations when CWD is absent for longer periods of time.

We found that $P$. lata was the most common cockroach associated with CWD in pine forests at the Savannah River Site. Conversely, P. divisa, another common wood cockroach, was found almost exclusively on the bark of living pines. It was rarely observed in logs or snags. Hebard (1943) also collected this species from dry pinelands and considered it to be abundant in Georgia.

$P$. lata was the most common cockroaches active on pine boles at night, followed by A. gemma, P. divisa, $P$. fulvescens, and C. lutea lutea, respectively. A. gemma was the second most common wood cockroach encountered during nocturnal observations of pine trees, and the second most common genus collected from pine boles (Horn 2000). Horn (2000) observed $>800$ A. gemma cockroaches under burlap bands during a 15-mo period. Like P. divisa, A. gemma were found primarily on the boles of live pines, which is consistent with Hebard's (1943) observations that this species is mainly arboreal. 
Male P. lat $a$ were the first to molt into adults in the laboratory. In the field, males started to appear in late April, and females appeared about 2 wk later. Males lived $91 \mathrm{~d}$ in the laboratory and were present in the field for approximately the same amount of time from late April until early August. Female P. lata lived $>2$ mo longer than males in the laboratory and were present in the field long after males disappeared. $P$. lata had only one generation per year. They overwintered as nymphs that were active whenever temperatures permitted. The life cycles of Parcoblatta spp. appear to be similar throughout their range consisting of one generation/year that overwinters as nymphs. Adults emerge in the spring and live for several months producing oothecae throughout the adult stage (Cantrall 1943, Dakin and Hays 1970). However, nymphs were abundant throughout the year suggesting that some may take more than $1 \mathrm{yr}$ to develop.

Cochran (1986) found that P. fulvescens and P. pennsylvanica produce new oothecae every $7-8 \mathrm{~d}$. Likewise, we found $P$. lata produced new oothecae every $7 \mathrm{~d}$ and produced an average of 12.6 oothecae/female, although one female produced 21 oothecae. Oothecae of $P$. lata had an average of 41 eggs, and we estimated that under optimal conditions females produce 517 offspring during their lifetime.

Five species of wood cockroaches were collected in pine forests of the Savannah River Site. Of these, P. lata was most prevalent, occurring in a wide range of habitats. It is unclear what effect reduction of CWD would have on the wood cockroach community in pine forests, but the large number of wood cockroaches associated with CWD suggests that it is an important habitat. An understanding of wood cockroach habitat requirements and how forest management affects wood cockroach abundance will help in maintaining adequate numbers for red-cockaded woodpeckers and other bark-foraging birds.

\section{Acknowledgments}

We thank Todd Kuntz for technical assistance during this project and A. Appel and C. Gemeno for reviewing the manuscript. Funding was provided by the Department of Energy, Savannah River Operations Office through the USDA Forest Service Savannah River under Interagency Agreement DE-IA09-76SR00056. The Savannah River Site is a National Environmental Research Park.

\section{References Cited}

Appel, A. G., and L. M. Smith II. 1996. Harborage preferences of American and smokybrown cockroaches (Dictyoptera: Blattidae) for common landscape materials. Environ. Entomol. 25: 817-824.

Appel, A. G., and L. M. Smith II. 1999. Perception and repellency of moving air by American and smokybrown cockroaches (Dictyoptera: Blattidae). J. Econ. Entomol. 92: $170-175$

Appel, A. G., D. A. Reierson, and M. K. Rust. 1983. Comparative water relations and temperature sensitivity of cockroaches. Comp. Biochem. Physiol. 74A: 357-361.
Atkinson, T. H., P. G. Koehler, and R. S. Patterson. 1991. Catalog and atlas of the cockroaches (Dictyoptera) of North America North of Mexico. Misc. Publ. Entomol. Soc. Am. 78: 1-86.

Avery, T. E. 1975. Natural resources measurements. McGraw-Hill, New York, NY.

Blatchley, W.S. 1920. Orthoptera of Northeastern America, Nature Publ. Co., Indianapolis, IN.

Benson, E. P. 1988. Ecology and control of the smokybrown cockroach, Periplaneta fuliginosa (Serville), in South Carolina. Ph.D. dissertation, Clemson University, Clemson, SC.

Bolen, E. G., and W. L. Robinson. 1995. Wildlife ecology and management. Prentice Hall. Englewood Cliffs, New Jersey.

Brenner, R. J. 1988. Focality and mobility of some peridomestic cockroaches in Florida (Dictyoptera: Blattaria). Ann. Entomol. Soc. Am. 81: 581-592.

Brimley, C. S. 1908. Notes on the Orthoptera of Raleigh, North Carolina. Entomol. News 19: 16-21.

Cantrall, I. J. 1943. The ecology of the Orthoptera and Dermaptera of the George Reserve, Michigan Misc. Publ. Mus. Zool. Univ. Michigan 54: 1-182.

Carmichael, D. B., Jr., and D. C. Guynn, Jr. 1983. Snag density and utilization by wildlife in the upper piedmont of South Carolina., pp. 107-110. In J.W. Davis, G. A. Goodwin, A. Gregory, R. A. Ockenfels [Tech. Coords.]. Proceedings, Symposium on snag habitat management. 1983. June 7-9. Flagstaff, AZ. General Technical Report RM-99. USDA, Forest Service, Fort Collins, CO.

Cochran, D. G. 1986. Biological parameters of reproduction in Parcoblatta cockroaches (Dictyoptera: Blattellidae). Ann. Entomol. Soc. Am. 79: 861-864.

Cornwell, P. B. 1968. The cockroach, vol. 1. Hutchinson, London.

Dakin, M. E., and K. L. Hays. 1970. A synopsis of Orthoptera (sensu lato) of Alabama. Ala. Agric. Exp. Stn. Bul. No. 404, pp. 118.

Edmunds, L. R. 1952. The oviposition of Prosevania punctata (Brulle): A hymenopterous parasite of cockroach egg capsules. Ohio J. Sci. 52: 29-30.

Elton, C. S. 1966. Dying and dead wood. The pattern of animal communities. J. Wiley, New York.

Gorton, R. E. 1980a. A comparative ecological study of the wood cockroaches in northeastern Kansas. Univ. Kansas Sci. Bull. 52: 21-30.

Gorton, R. E. 1980b. Behavioral and ecological correlations within a cockroach community. J. Kansas Entomol. Soc. 54: 278-284.

Hanula, J. L., and R. T. Engstrom. 2000. Comparison of red-cockaded woodpecker (Picoides borealis) nestling diet in old-growth and old-field longleaf pine (Pinus palustris) habitats. Am. Midl. Nat. 144: 370-376.

Hanula, J. L., and K. E. Franzreb. 1995. Diet of nestling red-cockaded woodpeckers in the Upper Coastal Plain of South Carolina. Wilson Bull. 107: 485-495.

Hanula, J. L., and K. E. Franzreb. 1998. Source, distribution, and abundance of macroarthropods on the bark of longleaf pine: potential prey of the red-cockaded woodpecker. For. Ecol. Manag. 102: 89-102.

Hanula, J. L., D. Lipscomb, K. E. Franzreb, and S. C. Loeb. 2000. Diet of nestling red-cockaded woodpeckers at three locations. J. Field Ornithol. 71: 126-134.

Harmon, M. E., J. F. Franklin, F. J. Swanson, P. Sollins, S. V. Gregory, J. D. Lattin, N. H. Anderson, S. P. Cline, N. G. Aumen, J. R. Sedell, G. W. Lienkaemper, K. Cromack, Jr., and K. W. Cummins. 1986. Ecology of coarse woody 
debris in temperate ecosystems. Adv. Ecol. Res. 15: 133302.

Hebard, M. 1917. The Blattidae of North America north of the Mexican boundary. Mem. Am. Entomol. Soc. 2: 1-284.

Hebard, M. 1943. The Dermaptera and orthopterous families Blattidae, Mantidae, and Phasmidae of Texas. Trans. Am. Entomol. Soc. 63: 239-311.

Helfer, J. R. 1987. How to know the grasshoppers, cockroaches, and their allies. Wm. C. Brown Co., Dubuque, IA.

Horn, G. S. 2000. Relationship of coarse woody debris to red-cockaded woodpecker prey diversity and abundance. M.S. thesis, University of Georgia, Athens.

Lawson, F. A. 1967. Ecological and collecting notes on eight species of Parcoblatta (Orthoptera: Blattidae) and other cockroaches. J. Kansas Entomol. Soc. 40: 267-269.

McCarthy, B. C., and R. R. Bailey. 1994. Distribution and abundance of coarse woody debris in a managed forest landscape of the central Appalachians. Can. J. For. Res. 24: 1317-1329.

McMinn, J. W., and D. A. Crossley, Jr. (Eds.) 1996. Biodiversity and coarse woody debris in southern forests. USDA Forest Service, General Technical Report SE-94, Asheville, NC.

Oswalt, D. A., A. G. Appel, and L. M. Smith II. 1997. Water loss and desiccation tolerance of German cockroaches (Dictyoptera: Blattellidae) exposed to moving air. Comp. Biochem. Physiol 117A: 477-486.
Prinzing, A. J. 2001. Use of shifting microclimatic mosaics by arthropods on exposed tree trunks. Ann. Entomol. Soc. Am. 94: 210-218.

Rau, P. 1940. The life history of the wood cockroach Parcoblatta pennsylvanica DeGeer (Orthoptera: Blattidae). Entomol. News 51: 4-9, 33-35.

Roth, L. M. 1966. Water changes in cockroach oothecae in relation to the evolution of ooviviparity and vivaparity. Ann. Entomol. Soc. Am. 60: 928-946.

Roth, L. M. 1968. Oothecae of the Blattaria. Ann. Entomol. Soc. Am. 61: 83-111.

SAS Institute. 1985. SAS guide for personal computers. Version 6 ed., SAS Institute, Cary, NC 378 pp.

Smith, L. M., II, A. G. Appel, T. P. Mack, and G. J. Keever. 1999. Preferred temperature and relative humidity of males of two sympatric Periplaneta cockroaches (Blattodea: Blattidae). Environ. Entomol. 28: 935-942.

Van Lear, D. H. 1996. Dynamics of coarse woody debris in southern forest ecosystems, pp. 10-17. In J. W. McMinn and D. A. Crossley, Jr. [eds]. Biodiversity and coarse woody debris in southern forests. USDA Forest Service General Technical Report SE-94, .

Received for publication 11 December 2001; accepted 18 June 2002 